\title{
Chapter 5 \\ Japanese Experts on Jews, Judaism, and Zionism
}

We have noted that in Major General Higuchi Kiicihiro's headquarters in Siberia there were a number of officers who specialized in Jewish affairs. The need for specialists in Jewish affairs arose when soldiers and officers belonging to the Japanese expeditionary force in Siberia had to deal with tens of thousands of Jews who lived in Siberia and Manchuria. The need to gather intelligence about this community was great, if only to prevent clashes between White Russians and Jews in Manchuria. Jews could also be a source of intelligence about the Soviet Union. After the departure of Japanese forces from Siberia in 1922, the Japanese military presence on the Asian mainland was concentrated in the Japanese-leased territory of Liaotung in southern Manchuria. Japanese army units had been stationed there as part of the 1905 peace treaty between Japan and Tsarist Russia that had ended the Russo-Japanese War. The units posted there were called the Kwantung Army, and their mission was to safeguard and advance Japanese interests in Manchuria, expand them if the opportunity arose, and obtain intelligence on all elements that could stand in the way of Japan's goals.

Initial intelligence about Jews came from White Russian refugees, some of them civilians but most of them former Tsarist soldiers and officers who had escaped from the Soviet Union after the Bolshevik Revolution. These individuals had a pernicious influence on the Japanese officers with whom they came into contact, and were the only channel though which Japanese officers could glean intelligence about Jews. Their negative opinions were due to their hatred of the Bolshevik regime, which they claimed was led by Jews. There were in fact many Jews in the upper echelons of the Soviet leadership, such as the head of the NKVD internal security agency Genrich Yagoda (1891-1938), Stalin's deputy Lazar Kaganovich (1893-1991), Stalin's personal secretary and later the editor of Pravda Lev Machlis (1889-1953), Leningrad party boss Grigory Zinoviev (1883-1936), Politbureau member Lev Kamenev, and Stalin's arch-rival, Red Army founder Leon Trotsky. 
Among the leading Jewish intellectuals, artists, writers, and poets who were part of the establishment there stood out the film director Sergei Eizenstein (1898-1948), journalist Ilia Ehrenburg (1891-1967), and poets Isaac Babel (1894-1940) and Ossip Mandelshtam (1891-1938). In Stalin's inner circle were Jews such as Paulina, the Jewish wife of prime minister and later foreign minister Vyacheslav Molotov. Such a high concentration of Jews in the highest echelons of the Soviet regime only strengthened fears among Japanese officers regarding the influence of Jews on policy- and decision-makers of the Soviet Union. This was also a proof of the Jewish ability to penetrate into the highest levels of a rising power-in this case the communist Soviet Union, a potential enemy of Japan.

Two Japanese officers became known as the country's leading experts on Jews. Both served in Higuchi's headquarters, which was responsible for special duties and was mainly used for gathering intelligence. One was Colonel Yasue Norihiro and the other Naval Captain Inuzuka Koreshige. ${ }^{1}$ The role of these experts was to advise the Japanese command on what they should do with the thousands of Jewish refugees who escaped from the Soviet Union after the Bolshevik Revolution and settled primarily in Manchuria's main city, Harbin, whose Jewish community in the early 1920's already numbered some 15,000 souls. It must be noted that the military careers of these two experts were not stellar, and that they did not stand out in any way apart from their linguistic abilities. ${ }^{2}$

Yasue was born in 1888 to a samurai family. At age 19 he entered Japan's Imperial Military Academy, and despite poor health managed to graduate in 1909. His military career was unexceptional, but in 1917 he was sent to study Russian at the Tokyo Foreign Languages School. His knowledge of Russian led to his assignment to Siberia in 1918, where he served as a liaison officer to Semyonov. This gave him the chance to meet a number of White Russian, anti-Bolshevik, and antisemitic officers, and thus began his career as a Jewish affairs specialist.

Inuzuka was born in 1890. He joined the navy after graduating from high school, enrolling in the Imperial Naval Academy, from which he graduated in 1912. During the First World War he served on board a number of vessels in the Mediterranean Sea, and at the end of the war he was stationed aboard a warship anchored off the port of Vladivostok. There he read The Protocols of the Elders of Zion for the first time, and was impressed with the "authenticity" of this forged document.

While Inuzuka never served in Siberia, Yasue did and used his Russian language skills to converse with Harbin's two largest foreign communities: the 
White Russians and the Jews. In the 1920's he and Inuzuka, after many conversations with White Russians and much consideration of Russian material on Jews, came to the conclusion that the Jews had become a major force in the world in the early parts of that decade, and that Japan must adopt a restrained policy towards them and attempt to win their goodwill in order to promote the continental interests of the Empire and win sympathy and understanding in America.

Their acceptance of the concept that the Jews possessed vast political and economic power was due partly to the antisemitic ideas adopted by Yasue and Inuzuka from the White Russian émigrés. Yasue undertook to translate the Protocols of the Elders of Zion to Japanese in 1924, and in the introduction to this infamous tract he in fact demonstrated that he subscribed to some of the antisemitic ideas contained in it. However, he also learned to appreciate and value the imagined and real power of the Jews and counselled his superiors to beware of their influence. He began to warn his superiors of the slow penetration of Jews into Japan in the guise of refugees, and suggested the possibility of their slow penetration into the nascent trade union movement and the Japanese Communist Party, which was established in 1926. In this manner, he warned, the Jews would add to the social upheaval and instability that already prevailed in some areas of Japan's major cities. Of course, none of this ever happened.

In the mid 1930's, Inuzuka was stationed in Shanghai and came into contact with the large Jewish community of that city. This familiarity strengthened his belief in the vast powers of world Jewry, and he supported the scheme of mobilizing German Jews to settle in Manchuria. In 1939, on the eve of World War II, Captain Inuzuka published an article in which he claimed that Japan faced a grave danger from the Jews. This danger began, according to him, in the days of Marco Polo-described by Inuzuka as Jewish — and later by another Jew: Christopher Columbus. Like Yasue, he argued that if Japan pursued an adroit policy, it could derive much benefit from the Jews. He too was influenced by Nazi racial doctrines. From March 1939 to April 1942, he served as the head of the Japanese Navy Advisory Bureau on Jewish Affairs and was deeply involved in formulating Japan's policies on the Jews of Shanghai.

There is no evidence that these two Jewish affairs experts ever made an attempt to study Jewish history in depth, to read books and articles on Judaism, learn rudimentary Hebrew or even Yiddish, or to understand the major foundations of the Jewish religion, such as the Jewish Bible and the commentaries of the Talmud. Since they received much of their knowledge of 
Jewish affairs from White Russians-and mainly White Russian officersmany of whom were openly antisemitic, it could not be expected that they would be educated on the positive aspects of Judaism. Nonetheless, for the requirements of their superior officers, their knowledge seems to have been sufficient. They were expected to deal with the leadership of the Jewish communities in Manchuria and later in Shanghai in order to ensure their support for Japan's policies in Asia. They were also expected to obtain intelligence on the Soviet Union, to be gathered from Jews in Harbin who still had many relatives in Russia.

However, there were other people in Japan who became interested in Jews and Judaism. Some Japanese intellectuals even displayed a friendly and positive interest in Zionism. Among them were Uchimura Kanzo (1861-1930), Nitobe Inazo (1862-1933), Tokutomi Kenjiro (1868-1927), and Professor Yanaihara Tadao (1893-1961). The latter lectured on colonial policy at Tokyo University, and wrote in one of his articles that, "The Zionist Movement is no more than an experiment to guarantee the Jews the right to emigrate and to settle, in order to create a center for Jewish national culture." He added that the Zionist claim that the Jewish people deserve a national state of its own reflects a true national problem, and that the cooperative system of the Jewish settlements in Palestine was worthy of adoption by Japan. ${ }^{3}$

\section{The Specialists and Zionism}

In the framework of acquiring knowledge on Jews and Zionism, the experts sought information that would help them establish Japan's policy toward the Zionist movement and wished to study what exactly the Zionists were aiming to achieve in Palestine. It turned out that some Japanese officers had already been introduced to the ideology of the Zionist movement over the course of the Russo-Japanese War by Japan's most famous Jewish prisoner of war, Yoseph Trumpeldor, who organized a Zionist cell and study groups in the Hamadera prisoner-of-war camp near Osaka. It is not known if the officers who guarded the Hamadera camp shared what they learned with higher military authorities or the Japanese government. The interest of the Japanese government and people in an independent state for the Jews in particular, and in problems of the Middle East in general, was virtually non-existent. Japan had few consular or diplomatic representatives in the Middle East, and had little information on the rise of the Arab national movement-which surprisingly had drawn much encouragement from 
Japan's victory over Russia in 1905. Until World War I, the Japanese government had no cause to take a stand regarding the Zionist movement and its aspirations, partly out of sheer non-interest and partly because no authorized Zionist body ever suggested that it do so. The leaders of the Zionist movement had many more immediately relevant things to think about during the first decade of the existence of the World Zionist Organization.

There is no evidence of any contact between Japanese officials and the Zionist Association that was established in Nagasaki in 1905, which offered assistance with food and Hebrew texts to Trumpledor and his fellow Russian Jewish prisoners of war. The need to obtain Japan's support of Zionist aspirations in Palestine arose toward the end of the First World War, when Japan joined Britain, France, Italy, Tsarist Russia (until January 1918), and beginning in April 1917 the United States as a member of the coalition against the German, Austro-Hungarian, and Ottoman Empires. Since a major foundation of Japan's foreign policy was its treaty of friendship with Britain, it appeared to the Zionist leadership to be a power that could play a potentially important role in shaping the post-war arrangements. ${ }^{4}$

The Zionists, who were obviously focused on the future of Palestine, realized that the power that was about to conquer Palestine from the Turks was Britain. In the early stages of the War, they had already concluded that they would have to link the fate of Zionism and its goal of establishing a Jewish state in Palestine with the British Empire, and their major achievement was the Balfour Declaration of November 2, 1917. Following this proclamation of support for Zionist aims by the British government, the Zionist leadership sought to obtain declarations of support for the Balfour Declaration from other major powers. The Shanghai Zionist Association was charged with the task of seeking the support of the three independent nations of Asia-Thailand, Japan, and China. The Japanese government expressed its support in various ways on a number of occasions. In fact, on September 24, 1918, the president of the Shanghai Zionist Association, Elie Kadourie, wrote to the Japanese embassy in Paris to seek the support of Japan for the Balfour Declaration. That embassy replied on December 27 that Japan's foreign minister Uchida Yasuya (1865-1936) stated that "the Government of Japan was happy to hear of the deep desire of the Zionists to establish a Jewish national homeland in Palestine and that it sympathizes with the implementation of their aspirations." Another expression of support was in the form of a reply to a letter written on January 3, 1919, to Japan's Ambassador to London Chinda Sutemi (1857-1929) by the 
Chairman of the Zionist Federation of Great Britain, Dr. Chaim Weizmann, seeking Japan's support for the Balfour Declaration. Chinda replied three days later saying that his government noted with pleasure Zionist aspirations to establish a national Jewish homeland in Palestine and viewed with favor the implementation of this aspiration on the proposed basis. Chinda also noted that the Japanese government had already sent a letter in this spirit to the Zionist Association of Shanghai in December 1918.

On the eve of the meeting of the four superpowers in San Remo in April 1920 to decide upon the granting of the Mandate over Palestine to Britain, Japan supported the granting, and Uchida Yasuya had already instructed Japan's consul general in Shanghai to write a letter on his behalf to the local Zionist Association congratulating the Zionists for this achievement. He added that he had followed closely the progress of the Zionist movement, which had won this noteworthy achievement. When the plenary session of the League of Nations voted on July 22, 1922, on granting the Palestine mandate to Britain, Japan translated its verbal support into political action and voted in favor. For his role Uchida was honored by the Zionist Movement, which inscribed his name in the Golden Book of the Jewish National Fund in Jerusalem. On the tenth anniversary of the Balfour Declaration, in November 1927, the Shanghai Zionists once again sought a declaration of support from the Japanese government. This time, Prime Minister Tanaka Giichi sent his greetings and noted the impressive achievements of the creation of national Jewish institutions in Palestine.

Why did Japan support the Zionists' aspirations in the 1920's? What lay behind the early Japanese support for Zionism? There were a number of very sober and well-calculated policy considerations involved. Four main reasons stand out: First, Japan was an ally of Britain during the First World War, and supported Britain's territorial demands and interests in the Middle East hoping to receive in return British support for its territorial ambitions in East Asia and the Pacific. Therefore, maintaining good relations with Britain was a cornerstone of Japanese foreign policy since the signing of the first Anglo-Japanese Alliance in 1902. Second, the highly exaggerated assessment and image of the well-connected wealthy Jews and the help they provided Japan during the Russo-Japanese War had to be considered, and perhaps was even rewarded in this manner. Third, the ability of the Zionist Organization to obtain the Balfour Declaration and subsequent declarations of support by the French and American governments impressed the Japanese government deeply. Japan saw the Zionist Organization as a powerful instrument of world Jewry which had vast influence over various 
governments. Fourth, it is important to note that the price paid by Japan for its support of Zionism was meager. Its support did not cost it the friendship of the Arabs (which it would have in the 1950's or later). Japan began to show growing interest in the Arab states only beginning in the mid-1920's. The absence of interest, knowledge, and understanding in Japan of Arab national aspirations helped the Zionists gain Japan's support. Furthermore, this support did not require of Japan any political, financial, or military effort. At most it was expressed in letters of support written to Zionist associations and in favorable votes in the League of Nations. Perhaps another reason had to do with the Shanghai Zionist Association, headed by Elie Kadourie (1865-1922), a member of the well-known and wealthy Jewish family which had large-scale business interests in Japan. ${ }^{5}$

The Japanese media showed almost no interest in Zionism or Palestine, and the few reports made on the topic demonstrated a lack of understanding. An outstanding example of this can be seen in coverage of the visit of Israel Cohen, who visited Japan, China, and Australia between May 1920 and May 1921 as an emissary of the Zionist Executive in London. He spent ten days in Japan in December 1920, held two public meetings with the Jewish communities in Yokohama and Kobe, and met with the British ambassador in Tokyo, but made no contact with the Japanese government. After the meeting in Yokohama, the daily newspaper Asahi Shimbun wrote that the Jews had held a meeting in the office of the Jewish community of Yokohama to discuss the creation of a "Jewish Kingdom" (sic). The same paper also called Cohen a member of the Jewish royal family. ${ }^{6}$

Contact between the Jewish community of Palestine and the Zionist Executive in Jerusalem in the 1920's was maintained through the consul general of Japan in Port Said, who visited Palestine in 1926 to gather intelligence. Various reports emanating from Palestine prompted the Japanese government to learn more about that country and the Jewish enterprise there. Some officers may have heard about the Zionist effort from the Jews in Harbin who maintained close contact with the Zionist leadership in Palestine. It is not coincidental that the job of learning more about Palestine fell on Colonel Yasue.

After returning to Japan from Siberia and Manchuria, Yasue had published a number of articles on Jewish subjects under a different name, because as an active-duty officer in the Japanese army it would have been inappropriate to publish under his own name. One of the articles was called "The Movement for the Establishment of a Jewish State." Yasue was later promoted by War Minister Shirakawa Yoshinori (1869-1932), who 
posted him to the imperial military headquarters in Tokyo. In the spring of 1927, Yasue was dispatched to Europe and Palestine to gather intelligence on what was already known as the "Jewish Question." He arrived in Palestine on December 8, 1927, accompanied by the pastor Sakai Katsuhisa (or Shogun). Their arrival was noted in the Palestine Weekly. They spent twenty-four days in Palestine, five of them touring the country, guided by a local journalist, Moshe Medzini (1897-1983, the father of this writer), who had been asked by the Zionist Executive to be their guide. Born in Irkutsk, Medzini had studied in Harbin and lived for a year in Japan in 1919, and was able to speak Russian with Yasue and English with Sakai.

They toured Jerusalem, Tel Aviv, and Haifa, saw a number of moshavim and kibbutzim, and visited some of the new industrial plants of the Jewish community. They also visited the newly opened Hebrew University campus on Mt. Scopus in Jerusalem. Their visit seems to have been important to the Zionist Executive, and they met with the Head of the Executive Colonel Frederick Kisch (1888-1943) and with the British High Commissioner Lord Plumer (1857-1932). During their visit they also had talks with Chaim Kalvarisky-Margaliot (1868-1947), the head of the Arab Department of the Zionist Executive.

Upon their return, Yasue published several articles on his impressions of Palestine (and Europe), in which he expressed his admiration for what he saw and the Jewish ability to make the desert bloom. The American Jewish scholar David Kranzler, who read Yasue's diary, noted that Yasue wrote that in his reports to the Japanese government he had expressed his view that the Zionist enterprise in Palestine was part of an international Jewish plot, and explained that his hosts in Palestine sought to conceal this fact from him.

Pastor Sakai gave a number of lectures about Palestine upon his return to Japan, and even wrote to Kisch suggesting that the World Zionist Organization present Emperor Hirohito (1901-1989) with a gift on the occasion of his coronation in 1928. Kisch referred to Sakai as the "crazy Gentile" ("Meshugener Goy"), but thought that an album of photographs depicting the Jewish community in Palestine would be a fitting gift. It is not clear if the gift was ever sent to the Emperor. Hirohito's coronation was noted by the Israel Messenger, the publication of the Zionist Association of Shanghai, edited by Nissim Benjamin Ezra. The article written for the occasion expressed hope that a Japanese consul would be appointed to New Judea, and that Japan would actively assist the implementation of the Zionist dream in New Judea. 
However, the interest of the Japanese government in Zionism and in Palestine cooled somewhat after this point. Other, more pressing, concerns arose that occupied its attention. One notable exception had occurred already in the early 1920's after an outbreak of violence in Palestine, when the under-secretary general of the League of Nations, a Japanese diplomat named Sugimura Yotaro (1884-1939), granted an interview to the Israel Messenger in Shanghai. He deplored the lack of law and order in Palestine and identified himself as a strong believer in the renaissance of the national Jewish spirit. He claimed that Japan had made a commitment to help implement the dream of a national Jewish homeland in Palestine and was fully aware of the key roles played by Jews in human history and what all of humanity owed them. He even mentioned Albert Einstein (1879-1955), who had visited Japan in 1922. But on the whole, the Japanese government refrained from making pro-Zionist statements and was content to let the British administer their mandate over Palestine and thus determine the fate of the Zionist effort in that country. ${ }^{7}$

In the 1920's and 1930's the Middle East was a very low priority on Japan's foreign policy agenda. It is true that Japan imported large quantities of raw cotton from Egypt, and exported to Egypt as well: between 1921 and 1924 the Japanese exports to Egypt grew from 2.5 million to 13.5 million USD. In 1931, at the height of the global economic crisis, Japanese firms exported to Middle Eastern countries goods worth 20 million USD, and four years later the sum rose to 43 million. Japanese goods, mainly textiles, began to enter markets in Middle East nations such as Turkey, Iran, Trans-Jordan, and even Palestine. This trade convinced Britain to pressure the Egyptian government to abrogate the most-favored-nation clause in its relations with Japan. Japanese goods did not have a good reputation and were known for being shoddy. ${ }^{8}$ Despite the increase, even at its height, exports to Middle Eastern countries constituted only 3.3\% of Japan's overall exports.

Did the experts on Jews play any role in determining Japan's policy on Palestine? Most likely they did not. They were far more concerned with establishing and maintaining ties with the Jewish refugees who were beginning to arrive in Manchuria in growing numbers and with the leaders of the Harbin Jewish community. There is no record of Japanese statements referring to the 1936-1939 Arab rebellion in Palestine, to the Peel's Commission recommendation of partitioning Palestine in 1937, or to the 1939 White Paper policy that severely limited Jewish immigration to Palestine and forbade the sale of land to Jews in a large part of that country. Since Japan 
withdrew from the League of Nations in 1933 over the Manchurian crisis, it was no longer represented in the League's Mandates Commission, a body to which the British were to provide an annual report on developments in the Palestine Mandate. Beginning in the mid-1930's, Germany replaced Britain as the focus of Japan's quest for alliances. In November 1936, Japan joined Germany in the Anti-Comintern Pact against Soviet Communism.

After the outbreak of the second Sino-Japanese War in July 1937, Japan experienced increasing problems with Britain in China, including British arms shipments to Chiang Kai-Shek's nationalist forces via the Burma Road. Palestine and its Jewish community were now relegated to the lowest priority in Japan's diplomacy. Japan was not yet dependent on Arab oil, as it would become starting in the mid-1950's, and so there was even less reason to be concerned with the Middle East. Japan's major interest, as far as Jewish matters was concerned, was focused on the Jewish community of Manchuria, which since 1931 had become the direct responsibility of the Japanese government. Harbin was the key city of this large community. 